\title{
Pelaksanaan Perjanjian Sewa Menyewa Rumah Susun dan Akibat Hukumnya dalam hal Terjadi Wanprestasi
}

\author{
Jefri Alzamzami*, Leli Joko Suryono \\ Program Studi Hukum, Fakultas Hukum, Universitas Muhammadiyah Yogyakarta, Indonesia \\ *Korespondensi: jefri.al-zamzami.2015@law.umy.ac.id
}

Info Artikel

Diajukan:05-05-2021

Direview:02-06-2021

Direvisi:24-06-2021

Diterima:28-06-2021

DOI: $10.18196 / \mathrm{mls} . v 2 i 3.12075$

\section{Abstrak}

Perjanjian yang terjadi di Rumah Susun Grahabinaharapan adalah Perjanjian Sewa-menyewa Rumah Susun antara Dinas Pekerjaan Umum Perumahan dan Kawasan Permukiman UPT Rusunawa sebagai yang menyewakan dan masyarakat berpenghasilan rendah sebagai penyewa. Tujuan penelitian ini untuk mengetahui Bagaimana Pelaksanaan Perjanjian Sewa Menyewa Rumah Susun dan akibat hukum dalam hal terjadinya wanprestasi di Rumah Susun Grahabinarapan Yogyakarta. Jenis penelitian ini adalah penelitian Normatif yang bersifat deskriftif kualitatif. Menggunakan data sekunder dengan melakukan wawancara dan mengelola data dari bahan hukum primer dan bahan hukum sekunder. Berdasarkan analisi yang telah dilakukan hasil dari penelitian ini adalah Pelaksanaan sewa menyewa rumah susun di grahabinaharapan dilaksanakan dengan bentuk tertulis, suatu perjanjian dapat berakhir apabila jangka waktu yang telah ditentukan telah berakhir. Akibat hukum wanprestasi dalam perjanjian sewa menyewa rumah susun di grahabinaharapan adalah diberikan surat peringatan kepada penyewa agar segera membayar sewa rumah susunya. Tetapi apabila peringatan tersebut tidak di laksanakan oleh penyewa hingga surat peringatan ketiga maka perjanjian sewa menyewa tersebut akan diputuskan atau diakhiri oleh pihak yang menyewakan yaitu Dinas Pekerjaan Umum Perumahan dan Kawasan Permukiman UPT Rusunawa sesuai dengan yang telah disepakati sebelumnya didalam surat Perjanjian sewa menyewa.

Kata kunci: Akibat Hukum, Perjanjian Sewa Menyewa, Wanprestasi.

\section{Pendahuluan}

Kebutuhan akan rumah merupakan kebutuhan yang mendasar bagi manusia setelah pangan dan sandang. Kebutuhan rumah merupakan kebutuhan akan tempat tinggal guna untuk tempat bernaung bersama-sama keluarga yang mana dapat melindungi dari segala cuaca dan gangguan alam dan mahkluk hidup lainnya, serta berfungsi sebagai pusat pendidikan keluarga. Pemenuhan terhadap kebutuhan rumah semakin sulit terpenuhi, seiring dengan pertumbuhan penduduk yang kian hari semakin besar mengakibatkan harga tanah semakin tinggi. Salah satu upaya untuk mendorong terhadap pemenuhan kebutuhan terhadap rumah, diperlukan suatu penyediaan perumahan yang disediakan baik oleh pemerintah maupun swasta khususnya bagi masyarakat berpenghasilan rendah. Hal ini dikarenakan secara umum pengeluaran untuk rumah merupakan komponen pengeluaran terbesar setelah pengeluaran pangan.

Pemerintah dalam hal ini yang memiliki peran penting dalam penyelenggaraan perumahan dan permukiman melalui programnya berupa pembangunan rumah susun yang dapat disewa ditujukan untuk memenuhi kebutuhan akan tempat tinggal bagi masyarakat berpenghasilan rendah. Pengaturan perihal pentingnya pembangunan 
perumahan dan permukiman ini telah menjadi agenda pemerintah dengan menekankan pentingnya upaya untuk meningkatkan dan memperluas adanya permukiman dan perumahan yang layak bagi seluruh masyarakat dan karenanya dapat terjangkau seluruh masyarakat. Terjangkau bagi seluruh masyarakat berarti juga pemerintah harus mampu menyediakan perumahan atau tempat tinggal bagi masyarakat yang berpenghasilan rendah, dengan tetap memperhatikan unsur kelayakan tempat tinggal dalam lingkungan yang sehat, secara adil dan merata, serta mencerminkan kehidupan masyarakat yang berkepribadian bangsa Indonesia. Perumahan sendiri merupakan kumpulan rumah sebagai bagian dari pemukiman, baik perkotaan maupun perdesaan, yang dilengkapi dengan sarana prasarana dan ultilitas umum sebagai hasil upaya pemenuhan rumah layak huni. Rumah yang layak huni umumnya harus memenuhi persyaratan keselamatan bangunan dan kecukupan minimum luas bangunan serta kesehatan penghuninya.

Lingkungan yang sehat, aman, serasi dan teratur adalah lingkungan yang memenuhi persyaratan penataan ruang, persyaratan penggunaan tanah, penguasaan hak atas tanah, serta kelayakan sarana dan prasarana lingkungannya.

Rumah susun Grahabinaharapan yang terletak di Jl. Juminahan No. 1, Puworkinanti, Pakualaman Kota Yogyakarta merupakan kawasan yang telah dipersiapkan bagi masyarakat berpenghasilan rendah guna memenuhi rumah layak huni. Rumah susun merupakan bangunan gedung bertingkat yang dibangun dalam suatu lingkungan yang terbagi dalam bagian-bagian yang distruktural secara fungsional, baik dalam arah horizontal maupun vertikal dan merupakan satuan-satuan yang masingmasing dapat dimiliki dan digunakan secara terpisah, terutama unutuk tempat hunian yang dilengkapi dengan bagian bersama, benda bersama, dan tanah bersama. Pembangunan rumah susun berlandaskan pada asas kesejahteraan umum, keadilan, pemerataan, keserasian, dan keseimbangan dalam perikehidupan.

Pembangunan rumah susun bertujuan untuk :

1. Memenuhi kebutuhan perumahan yang layak bagi rakyat, terutama golongan masyarakat yang berpenghasilan rendah dan menjamin kepastian hukum pemanfaatannya.

2. Meningkatkan daya guna dan hasil guna tanah di daerah perkotaan dengan memperhatikan kelestarian sumber daya alam dan menciptakan lingkungan permukiman yang lengkap, serasi dan seimbang.

3. Memenuhi kebutuhan untuk kepentingan lainnya yang berguna bagi kehidupan masyarakat dengan tetap mengutamakan ketentuan sebelumnya.

Adanya pembangunan rumah susun ini juga sebagai upaya untuk mengurangi permukiman kumuh yang diakibatkan sebagai ketidakmampuan masyarakat dalam membangun rumah sebagai tempat tinggal. Adanya rumah susun ini diharapkan juga akan membuat tata ruang kota menjadi terbuka sehingga menjadi lebih lega, dan dalam hal ini juga membantu adanya peremajaan kota, pengurangan permukiman kumuh, dan 
selanjutnya menjadi daerah yang rapi, bersih, dan teratur, mengingat pembangunan rumah susun ini memang diperuntukkan bagi masyarakat yang kurang mampu dengan biaya yang terjangkau untuk masyarakat golongan ini.

Pemerintah dalam hal ini yaitu UPT Rusunwa Dinas Pekerjaan Umum Perumahan dan Kawasan Permukiman Kota Yogyakarta yang berwenang mengelola Rumah Susun Grahabinaharapan untuk kepentingan masyarakat berpenghasilan rendah Kota Yogyakarta. Dalam kepentingan ini, Dinas terkait dapat mengalihkan kepada masyarakat untuk mendapatkan suatu rumah dengan izin dan membayar sewa. Oleh karena itu muncullah suatu perikatan antara Pemerintah Kota yaitu Dinas Pekerjaan Umum Perumahan dan Kawasan Permukiman Kota Yogyakarta dengan Masyarakat yang disebut dengan perjanjian. Perjanjian tersebut seperti yang sering kita dengar yaitu Perjanjian Sewa menyewa. Sewa menyewa adalah suatu perjanjian dengan mana pihak yang satu mengikatkan dirinya untuk memberikan kepada pihak yang lain kenikmatan dari suatu barang, selama waktu tertentu dan dengan pembayaran suatu harga yang oleh pihak tersebut terakhir disanggupi permbayarannya. Pasal 1548 KUHPerdata tentang perjanjian sewa menyewa. ${ }^{1}$

Perjanjian sewa menyewa rumah susun juga akan menimbulkan suatu hak dan kewajiban diantara masing-masing pihak. Pihak penyewa mempunyai hak untuk menempati rumah susun yang disewa dalam suatu waktu tertentu yang telah ditentukan dan berkewajiban membayar sejumlah harga tertentu yang telah diperjanjikan. Pihak yang menyewakan rumah susun berhak atas pembayaran sejumlah uang tertentu dan berkewajiban menyerahkan unit hunian rumah susun kepada penyewa untuk masa waktu tertentu. Perjanjian sewa menyewa rumah susun dianggap sah dan mengikat pada saat tercapainya kata sepakat antara kedua belah pihak.

Dalam suatu Perjanjian Sewa menyewa atau Perjanjian yang lain, mungkin akan timbul perbuatan yang disebut Wanprestasi, adapun wujud dari Wanprestasi seorang debitur dapat berupa empat macam:

1. Tidak melakukan apa yang dijanjikannya, disanggupi akan dilakukannya.

2. Melakukan apa yang tetapi tidak sebagaimana diperjanjikan.

3. Melakukan apa yang diperjanjikan tetapi terlambat.

4. Melakukan sesuatu yang menurut perjanjian tidak boleh dilakukannya. ${ }^{2}$

Wanprestasi atau kelalaian mempunyai akibat-akibat yang begitu penting, maka harus ditetapkan lebih dahulu apakah si penyewa melakukan wanprestasi atau lalai, dan kalau itu disangkal olehnya maka harus dibuktikan dan diselesaikan secara musyawarah mufakat atau negosiasi antara yang menyewakan dan yang menyewa. Apabila tidak dapat diselesaikan secara musyawarah mufakat atau Negosiasi maka dapat diselesaikan

\footnotetext{
${ }^{1}$ Subekti R, (2014). Aneka Perjanjian. Surabaya: Citra Aditya Bakti, h. 39.

${ }^{2}$ Budiman. Sinaga. (2005). Hukum Kontrak dan Penyelesaian Sengketa. Jakarta: PT Raja Grafindo Tinggi, h. 55.
} 
dimuka hakim. Terkadang tidak mudah untuk mengatakan bahwa seseorang itu lalai. Karena mengenai perjanjian untuk menyerahkan suatu barang atau untuk melakukan suatu perbuatan, jika dalam perjanjian tidak diterapkan batas waktunya tetapi si penyewa akan dianggap lalai dengan lewatnya waktu yang ditentukan, pelaksanaan prestasi itu harus lebih dahulu ditagih atau diperingatkan bahwa yang menyewakan menghendaki pelaksanaan perjanjian. Pada perikatan-perikatan untuk menyerahkan sesuatu, wanprestasi biasanya berakibat penggantian kerugian. Hal ini sangat memuaskan apabila kita menghadapi sebuah perikatan yang terdiri atas penyerahan sejumlah uang.

Akan tetapi kurang memuaskan apabila prestasi itu terdiri atas penyerahan sebuah barang, apabila ada kesepakatan baru antara yang menyewakan dan penyewa. Dalam hubungan ini, telah dipersoalkan apakah perjanjian itu sudah batal karena kelalaian pihak penyewa atau kah harus dibatalkan oleh pengelola rumah susun. Tentu saja kedua belah pihak yang melakukan perjanjian sewa menyewa dapat juga membuat alternative ketentuan-ketentuan bahwa pembatalan ini dapat diucapkan secara musyawarah mufakat antara pihak yang menyewakan dan pihak penyewa. Sehingga perjanjian dengan sendirinya akan hapus manakala salah satu pihak tidak memenuhi kewajiban.

Dalam hal terjadinya wanprestasi pada sewa menyewa rumah susun grahabinaharapan kota Yogyakarta sesuai dengan ketentuan pada perjanjian sewa menyewa rumah susun grahabinaharapan kota Yogyakarta, maka pihak pengelola memberikan peringatan terlebih dahulu. Apabila hingga peringatan ketiga penyewa tetap tidak mengindahkan peringatan tersebut maka pihak pengelola akan mengakhiri perjanjian sewa menyewa yang dimaksud atau dengan perkataan lain penyewa yang wanprestasi tidak diperbolehkan untuk menempati lagi di rumah susun grahabinaharapan.

Berdasarkan uraian diatas peneliti tertarik untuk mengetahui bagaimana Pelaksanaan perjanjian sewa menyewa rumah susun dan akibat hukumnya dalam hal terjadi wanprestasi di Grahabinaharapan Yogyakarta. Tujuannya supaya penulis beserta masyarakat berpenghasilan rendah mengetahui lebih dalam mengenai prosedur sewa menyewa rumah susun di Grahabinaharapan serta akibat hukum yang ditanggung oleh penyewa bila melanggar ketentuan dalam perjanjian sewa menyewa tersebut

\section{Metode Penelitian}

Teknik pengumpulan data yang digunakan adalah wawancara kepada responden atau orang-orang yang terkait dngan tempat penelitian yaitu rumah susun Grahabinaharapan Yogyakarta. Hasil wawancara sebagai sumber primer akan diolah dengan teknik analisa kualitatif deskriptif.

Penggunaan sumber hukum primer yang berkaitan dengan bahan-bahan pokok penelitian dan berbentuk himpunan peraturan perundang-undangan. Selain itu bahan 
hukum sekunder di gunakan dalam membantu analisis yang berupa buku, jurnal, pendapat ahli dan hasil penelitian terkait. Sebagai pelengkap dan pendukung bahan hukum primer dan sekunder, dalam penelitian ini menggunakan bahan hukum tersier diantaranya berupa kamus dan ensikopedia. ${ }^{3}$

\section{Hasil dan Pembahasan}

Pengertian perjanjian menurut Pasal 1313 KUHPerdata yang berbunyi "suatu perjanjian adalah suatu perbuatan dengan mana satu satu orang atau lebih mengikatkan dirinya terhadap satu orang atau lebih lainnya". Dari peristiwa tersebut timbullah hubungan hukum antara dua orang tersebut yang dinamakan perikatan. Pengertian sewa menyewa adalah suatu perjanjian dengan mana pihak yang satu mengikatkan dirinya untuk memberikan kepada pihak yang lainnya kenikmatan dari suatu barang atau benda selama waktu tertentu dan dengan pembayaran suatu harga yang oleh pihak tersebut di sanggupi pembayarannya. Demikian definisi yang diberikan oleh pasal 1548 KUHPerdata mengenai perjanjian sewa menyewa tersebut.

Sewa menyewa sama halnya dengan jual beli dan perjanjian-perjanjian lain pada umumnya yaitu menggunakan asas konsensual artinya perjanjian sah dan mengikat pada waktu tercapainya kata sepakat mengenai unsur-unsur pokok yaitu barang dan harga. Sama halnya yang telah dilakukan oleh masyarakat berpenghasilan rendah di Yogyakarta, rumah susun dapat juga diartikan sebagai rumah susun yang tempat huniannya hanya dapat ditempati dengan cara menyewa. Masyarakat yang ingin menghuni rumah susun di kawasan tersebut harus menyewa terlebih dahulu dengan izin dari pengelola Dinas Pekerjaan Umum Perumahan dan Kawasan Permukiman UPT Rusunawa, hal ini membutuhkan suatu perjanjian sewa menyewa antara pihak pengelola dengan calon penghuni agar terjadi kepastian hukum bagi para pihak.

Seperti yang telah dikemukakan bahwa sumber perikatan yang terpenting adalah perjanjian, sebab dengan melalui perjanjian pihak-pihak dapat membuat segala macam perikatan, sesuai dengan asas kebebasan berkontrak yang tercantum didalam buku ke III KUHPerdata sebagaimana diatur dalam pasal 1338, akan tetapi kebebasan berkontrak tersebut bukan berarti boleh membuat perjanjian secara bebas dan sembarangan, melainkan harus memenuhi syarat-syarat tertentu untuk syarat sahnya suatu perjanjian.

Sebagaimana yang telah dijelaskan didalam Pasal 1320 KUHPerdata, ada 4 syarat yang diperlukan yaitu:

1. Sepakat mereka yang mengikatkan dirinya

Syarah sah ini maksudnya adalah suatu perjanjian harus ada kesepakatan dari para pihak tanpa adanya paksaan dan kekhilafan. Perjanjian yang dibuat harus dibuat dengan ikhlas dan kemauan sendiri. Di Rumah Susun Grahabinaharapan pelaksanaan perjanjian

\footnotetext{
${ }^{3}$ Mukti Fajar ND, Yulianto Achmad. (2009). Dualisme Penelitian Hukum Normatif \& Empiris. Yogyakarta: Pustaka Pelajar, h. 158.
} 
sewa menyewa tersebut dilakukan oleh para pihak dengan keadaan sadar dan tanpa paksaan. Para pihak dalam perjanjian disini adalah pihak yang menyewakan yaitu Kepala UPT Rusunawa Dinas Perkerjaan Umum Perumahan dan Kawasan Permukiman Kota Yogyakarta dengan pihak yang menyewa yaitu Masyarakat Berpenghasilan Rendah.

2. Kecakapan untuk membuat suatu perjanjian

Syarat sah ini maksudnya adalah kemampuan dan kecakapan para pihak untuk melakukan perbuatan hukum bagi orang-orang yang oleh hukum dinyatakan sebagai subjek hukum dan berwenang melakukan perbuatan hukum yaitu orang yang telah dewasa, dan wanita yang telah menikah. Para pihak dalam melaksanakan perjanjian sewa menyewa di Rumah Susun Grahabinaharapan telah dewasa para pihaknya dan telah dinyatakan cakap hukum sehingga sah untuk melakukan perbuatan hukum.

3. Suatu hal tertentu

Syarat sah ini menyangkut obyek hukum atau bendanya. Menyangkut wujud bendanya, bergerak atau tidak bergerak, objeknya jelas mengenai jenis barangnya, kualitasnya, dan lain-lain. Objek pokok dalam perjanjian dalam sewa menyewa ini telah jelas wujudnya dan termasuk Benda Tidak Bergerak yaitu berupa Hunian Rumah Susun disewakan dalam keadaan kosong, terawat dan terpelihara dengan baik.

4. Suatu sebab yang halal

Dalam syarat ini maksudnya adalah objek hukum yang menjadi pokok dalam perjanjian harus melekat hak yang pasti dan diperbolehkan oleh hukum. Tidak bertentangan dengan undang-undang dan kesusilaan. Perjanjian sewa menyewa yang dibuat oleh para pihak ini dalam pelaksanaanya objeknya tidak bertentangan dengan undang-undang dan kesusilaan.

Apabila wanprestasi yang dilakukan salah satu pihak dalam perjanjian timbal balik terjadi akibat dari keadaan memaksa (force majeure), maka perjanjian bisa menjadi batal.

Suatu perjanjian dapat lahir dari adanya kesepakatan, dengan hal itu pula maka suatu perjanjian sewa menyewa dapat juga berakhir. Berakhirnya perjanjian ini dikarenakan:

a. Perjanjian berakhir apabila ditentukan jangka waktunya oleh para pihak dalam perjanjian yaitu bahwa perjanjian tersebut akan berlangsung untuk jangka waktu tertentu.

b. Para pihak bersepakat mengakhiri perjanjian walaupun jangka waktu perjanjian belum berakhir.

c. Undang-undang menentukan batas waktu berakhirnya suatu perjanjian dalam Pasal 1066 ayat (3) KUHPerdata disebutkan bahwa "para ahli waris dapat mengadakan perjanjian untuk selama waktu tertentu untuk tidak melakukan pemecahan harta 
warisan", akan tetapi waktu perjanjian tersebut padaPasal 1066 ayat (4) KUHPerwaktu berlakunya dibatasi selama 5 (lima) tahun.

d. Para pihak atau undang-undang dapat menentukan bahwa dengan terjadinya peristiwa tertentu maka perjanjian akan dihapus.

e. Pernyataan penghentian perjanjian dapat dilakukan oleh kedua belah pihak atau salah satu pihak saja.

f. Keputusan hakim.

g. Tujuan perjanjian telah tercapai ${ }^{4}$

Dalam pelaksanaan Sewa menyewa rumah susun tentu terdapat prosedur didalamnya. Prosedur yang ditentukan untuk menyewa rumah susun pada salah satu rumah susun tentu ada perbedaan antara prosedur rumah susun yang satu dengan prosedur rumah susun yang lainnya. Namun secara umum prosedur rumah susun yang satu dengan yang lainnya hampir sama. Adapun prosedur pelaksanaan perjanjian sewa menyewa rumah susun antara masyarakat berpenghasilan rendah dengan UPT Rusunawa Dinas Pekerjaan Umum Perumahan dan Kawasan Permukiman Yogyakarta yaitu sebagai berikut :

1. Penyewa mengisi formulir pendaftaran yang diberikan pihak UPT Rusunawa untuk menjadi penyewa di rumah susun grahabinaharapan

2. Penyewa diharuskan melengkapi persyaratan-persyaratan pendaftaran yang diperlukan

3. Pihak UPT Rusunawa dan pihak penyewa membicarakan isi perjanjian dan sekaligus membahas kesepakatan dari isi perjanjian sewa menyewa rumah susun grahabinaharapan

4. Apabila kedua belah pihak sepakat terhadap isi perjanjian sewa menyewa rumah susun grahabinaharapan, selanjutnya para pihak menandatangani perjanjian rumah susun tersebut. Dengan terjadinya kesepakatan antara para pihak maka perjanjian sewa menyewa rumah susun grahabinaharapan tersebut telah mengikat para pihak atau telah sah dalam melakukan perjanjian sewa menyewa rumah susun.

Adapun Syarat-syarat yang harus dipenuhi oleh penyewa sebelum melakukan perjanjian sewa menyewa rumah susun di Grahabinaharapan adalah:

1. Melampirkan surat pernyataan belum memiliki rumah (bermatrai 6000)

2. Mengisi formulir pendaftaran

3. Melampirkan fotocopy kartu keluarga (C1) 1 lembar

4. Melampirkan fotocopy kartu tanda penduduk (KTP) 1 lembar

\footnotetext{
${ }^{4}$ Kartini Mulyadi, Gunawan Widjaja. (2008). Perikatan Yang Lahir Dari Perjanjian. Jakarta: Rajawali Pers, h. 40.
} 
5. Melampirkan surat nikah 1 lembar

6. Melampirkan slip gaji atau surat pengantar RT menerangkan pendapatan setiap bulan. $^{5}$

Apabila syarat-syarat tersebut telah dipenuhi, maka dapat dilakukanlah perjanjian sewa menyewa rumah susun tersebut.

Dalam perjanjian sewa menyewa rumah susun di grahabinaharapan sering menjadi kendala yaitu adanya penghuni rumah susun yang tidak tertib administrasi, tidak tertib administrasi disini yaitu tidak memenuhi kewajiban membayar uang sewa dan juga biaya-biaya lain setelah menempati rumah susun. Upaya yang dilakukan oleh pemerintah yakni Dinas Pekerjaan Umum Perumahan dan Kaswasan Permukiman UPT Rusunawa Kota Yogyakarta selaku pengelola untuk menghadapi kendala tersebut yaitu pihak pengelola cenderung lebih memperhatikan latar belakang mengapa penghuni tersebut tidak bisa membayar. Karena ada penghuni yang bener-benar tidak mampu tetapi ada juga yang karena alasan-alasan lain seperti malas atau menyepelekan kewajiban untuk membyara uang sewa. Untuk penghuni yang tidak bisa membayar karena memang benar-benar tidak mampu membayar uang sewa, pengelola tetap memperhatikan unsur kemanusiaan dengan memberikan kelonggaran waktu pembayaran namun tetap memberikan peringatan kepada penyewa tersebut, mengingat tujuan dari pembangunan rumah susun ini adalah untuk membantu masyarakat yang berpenghasilan rendah mempunyai tempat tinggal yang layak. Namun, apabila penghuni memang terbukti benar-benar menyepelekan kewajibannya untuk membayar uang sewa, maka pengelola akan bertindak lebih tegas dengan memberikan peringatan secara lebih keras dan apabila tetap tidak mau memenuhi kewajibannya, maka pihak pengelola akan langsung membatalkan perjanjian secara sepihak sesuai yang telah disepakati sebelumnya dalam perjanjian sewa menyewa rumah susun ini.

Sistem sewa yang diterapkan Dinas Pekerjaan Umum Perumahan dan Kawasan Permukiman UPT Rusunawa mengharuskan penyewa membayar terlebih dahulu sebelum menggunakan rumah susun. Jangka waktu sewa disepakati yaitu 3 tahun. Prosedur pembayaran yang diterapkan adalah pembayaran dilakukan tiap bulan selambat-lambatnya tanggal 10 pada tanggal yang sedang berjalan. Untuk Penyewa diharuskan membayar uang jaminan sebesar 3 kali uang sewa pada saat penandatanganan perjanjian sewa. Uang jaminan tersebut akan dikembalikan bila mana pihak penyewa tidak lagi menempati rumah susun. Uang jaminan merupakan uang yang menjadi jaminan apabila penyewa tidak melaksanakan prestasinya. Akan tetapi apabila penyewa tetap tidak melaksanakan prestasinya maka akan diberikan surat peringatan pertama, kemudian apabila setelah diberikan SP pertama tetapi penyewa tetap tidak melaksanakan prestasinya maka akan diberikan SP kedua hingga SP ketiga. Apabila sudah sampai SP ketiga penyewa tetap tidak melaksanakan prestasinya maka perjanjian

\footnotetext{
${ }^{5}$ Wawancara, dengan Bapak Agus Sularta selaku kepala UPT Rusunawa Dinas Pekerjaan Umum Perumahan dan Kawasan Permukiman Pada Tanggal 11 November 2019.
} 
sewa menyewa tersebut akan diputuskan atau diakhiri oleh pihak yang menyewakan yaitu Dinas Pekerjaan Umum Perumahan dan Kawasan Permukiman sesuai dengan yang telah disepakati sebelumnya didalam surat Perjanjian sewa menyewa. ${ }^{6}$

Walaupun perjanjian sewa menyewa tersebut telah mecapai kata sepakat antara dua belah pihak namun dalam bentuk suatu perjanjian tidak boleh dilupakan, meskipun sewa menyewa adalah suatu perjanjian yang konsensual serta memberikan kebebasan kepada masyarakat untuk mengadakan perjanjian yang berisikan apa saja asal tidak bertentangan dengan ketertiban umum dan kesusilaan. Akan tetapi didalam undangundang terdapat perbedaan dalam hal akbibat antara perjanjian sewa menyewa secara tertulis dan sewa menyewa secara lisan.

Proses pelaksanaan perjanjian sewa menyewa rumah susun selain adanya syarat syarat yang telah ditentukan dan harus dipenuhi, pelaksanaannya juga perlu untuk memperhatikan harga sewa dari objek. Harga sewa rumah susun bervariasi macamnya biasanya dibedakan berdasarkan lantai. Rumah susun yang disewakan oleh pihak pengelola haruslah dalam kondisi yang baik, layak untuk digunakan, dan siap pakai, tidak rusak agar pihak penyewa merasa puas kebutuhannya telah terpenuhi dan tidak ada pihak yang merasa dirugikan.

Berikut rincian harga sewa rumah susun Grahabinaharapan :

1. Hunian lantai 1, harga Rp. 75.000,-/Bulan

2. Hunian lantai 2, harga Rp. 305.000,-/Bulan

3. Hunian lantai 3, harga Rp. 295.000,-/Bulan

4. Hunian lantai 4, harga Rp. 285.000,-/Bulan

5. Hunian lantai 5, harga Rp. 275.000,-/Bulan

Bentuk perjanjian sewa menyewa rumah susun di grahabinaharapan yaitu dilakukan dengan secara tertulis. Bentuk perjanjian tertulis dengan akta dibawah tangan. Hal-hal yang tercantum dalam perjanjian sewa menyewa rumah susun tersebut adalah sebagai berikut:

1. Terdapat tanggal dibuatnya perjanjian sewa menyewa.

2. Subyek hukum yaitu para pihak yang terlibat dalam perjanjian sewa menyewa, yaitu :

a. Pihak pertama yang menyewakan yaitu UPT Rusunawa Dinas Pekerjaan Umum Perumahan dan Kawasan Permukiman

b. Pihak kedua yaitu pihak penyewa.

3. Objek barang yang disewakan yaitu rumah susun

\footnotetext{
${ }^{6}$ Ibid
} 
4. Terdapat jangka waktu sewa menyewa yang telah ditentukan oleh kedua pihak

5. Terdapat ketentuan besarnya uang sewa yang diwajibkan pihak penyewa untuk membayar biaya sewa

6. Terdapat ketetuan perjanjian kerja sama antara pihak yang menyewakan dan pihak penyewa yang terdiri dari :

a. Pihak yang menyewakan menyerahkan rumah susun yang disewakan tersebut dalam keadaan kosong berserta dengan fasilitasnya

b. Pihak penyewa menerima rumah susun dari pihak yang menyewakan dengan rincian seperti diatas dan cukup dibuktikan dengan penandatanganan perjanjian ini sebagai bukti tanda penerimaan yang sah.

c. Terdapat ketentuan apabila pihak penyewa terlambat untuk membayar biaya sewa.

d. Ketentuan bahwa pihak penyewa tidak boleh mengulang sewakan rumah susun kepada pihak lain.

e. Pihak penyewa tidak berhak untuk menggadaikan atau menjual kepada pihak manapun.

f. Pihak penyewa diwajibkan untuk menjaga, merawat, memelihara rumah susun dengan sebaik-baiknya, atas biaya sendiri

g. Tagihan pajak, iuran-iuran, sumbangan-sumbangan dan beban lainnya yang berhubungan dengan rumah susun tersebut semuanya dibayar dan ditanggung oleh pihak penyewa.

7. Hak dan Kewajiban para pihak

8. Tanda tangan para pihak diatas materai

Dalam suatu perjanjian yang dilakukan dalam bentuk tertulis, suatu perjanjian dapat berakhir apabila jangka waktu yang telah ditentukan telah berakhir. Akan tetapi dalam perjanjian sewa menyewa ini, untuk berakhirnya suatu perjanjian yaitu telah diatur oleh Pasal 1570 KUHPerdata yang menyatakan bahwa : "jika sewa dibuat dengan tulisan maka sewa itu berakhir demi hukum, apabila waktu yang ditentukan telah lampau, tanpa diperlukannya sesuatu pemberhentian untuk itu".

Begitu juga yang terdapat pada perjanjian sewa menyewa rumah susun di grahabinaharapan, yaitu perjanjian sewa menyewa berlaku selama tiga tahun, perjanjian tersebut berakhir apabila telah lewat dari tiga tahun sejak ditandatangani surat perjanjian namun apabila surat perjanjian yang baru belum dibuat atau masih dalam proses pembuatan, maka surat perjanjian yang lama masih berlaku. Dengan demikian, untuk mengetahui apakah surat perjanjian itu sudah berakhir atau belum harus dilihat dulu masing-masing perikatan dalam perjanjian. Oleh sebab itu, dalam perjanjian sewa menyewa tersebut dapat diketahui apakah perjanjian tersebut sudah berkahir atau belum yaitu dengan melihat perjanjian yang dibuat secara tertulis dimana didalamnya berisi 
tentang jangka waktu yang telah ditentukan. Seperti yang telah dijelaskan dalam Pasal 1570 KUHPerdata yang mengatur mengenai berakhirnya perjanjian sewa menyewa tersebut.

Di dalam suatu perjanjian yang terjadi selalu melahirkan suatu prestasi di mana prestasi yang wajib dipenuhi oleh pihak yang mengadakan perjanjian. Apabila salah satu pihak tidak dapat memenuhi suatu prestasi atau apa yang telah diperjanjikan maka terjadilah apa yang disebut dengan wanprestasi. Menurut $\mathrm{R}$ Saliman wanprestasi adalah sikap dimana seseorang tidak memenuhi atau lalai melaksanakan kewajibannya sebagaimana yang telah ditentukan dalam perjanjian yang telah dibuat antara kreditur dan debitur. Pasal 1238 KUHPerdata berbunyi "Debitur dinyatakan lalai dengan surat perintah atau dengan akta sejenis itu, atau berdasarkan kekuatan dari perikatan sendiri, yaitu bila perikatan ini mengakibatkan debitur harus dianggap lalai dengan lewatnya waktu yang ditentukan". Dari rumusan Pasal 1238 KUHPerdata diatas dapat diketahui bahwa ada dua kondisi kapan seseorang dianggap lalai atau cedera janji yaitu :

a. Dalam hal di tetapkan suatu waktu didalam perjanjian, tapi dengan lewatnya waktu tersebut (jatuh tempo) debitur belum juga melaksanakan kewajibannya.

b. Dalam hal tidak ditentukan suatu waktu tertentu, lalu kreditur sudah memberitahukan kepada debitur tetap juga tidak melaksanakannya kewajiban kepada kreditur.

Adapun wujud dari wanprestasi seorang debitur dapat berupa 4 (empat) macam:

a. Tidak melakukan apa yang dijanjikannya, disanggupi akan dilakukannya.

b. Melakukan apa yang tetapi tidak sebagaimana diperjanjikan.

c. Melakukan apa yang dijanjikanya tapi terlambat.

d. Melakukan sesuatu yang menurut perjanjian tidak boleh dilakukannya.

Untuk mengetahui sejak kapan debitur dapat dinyatakan dalam keadaan wanprestasi maka perlu diperhatikan apakah dalam perjanjian itu ditentukan tenggang waktu pelaksanaan pemenuhan prestasi atau tidak. Jika ditentukan maka pihak debitur harus memenuhi kewajiban tersebut. Jika tidak memenuhi kewajiban tersebut maka perjanjian dapat dibatalkan dan tidak berlaku bagi keduanya baik yang menyewakan maupun penyewa. Prestasi wajib dipenuhi secara keseluruhan agar perjanjian tersebut dapat berjalan dengan baik, tanpa merugikan kedua belah pihak. Adapun wujud dari wanprestasi yang dilakukan penyewa pada perjanjian sewa menyewa rumah susun di grahabinaharapan adalah keterlambatan pembayaran uang sewa.

Menurut Abdulkadir Muhammad wanprestasi atau tidak memenuhi kewajiban yang telah ditetapkan mengandung dua kemungkinan alasannya yaitu :

a. Karena kesalahan penyewa, baik karena kesengajaan maupun karena kelalaian. 
b. Karena keadaan memaksa (force majeure) jadi diluar kemampuan penyewa, penyewa tidak bersalah.

Akibat dari wanprestasi munculnya suatu ganti rugi bagi pihak yang merasa dirugikan. Menurut Nieuwenhuis, kerugian adalah berkurangnya harta kekayaan pihak yang satu disebabkan oleh perbuatan yang melanggar norma oleh pihak lain. Dalam KUHPerdata hanya mengatur tentang ganti rugi dari kerugian yang bersifat material (berwujud) yang dapat dinilai dengan uang, dan tidak mengatur ganti rugi dari kerugian yang bersifat immaterial, tidak berwujud (moral).

Pada wanprestasi, perhitungan ganti rugi dihitung sejak terjadinya kelalaian. Hal ini sebagaimana diatur Pasal 1237 KUHPerdata: "pada suatu perikatan untuk memberikan barang tertentu, barang itu menjadi tanggungan kreditur sejak sejak perikatan lahir. Jika debitur lalai untuk menyerahkan barang yang bersangkutan, maka barang itu, semenjak perikatan dilakukan, menjadi tanggungannya."

Menurut Subekti, ada empat akibat dari terjadinya wanprestasi, yaitu:

a. Membayar kerugian yang diderita oleh kreditur atau dengan singkat dinamakan ganti rugi

b. Pembatalan perjanjian atau juga dinamakan pemecahan perjanjian

c. Peralihan resiko

d. Membayar biaya perkara, kalau sampai diperkarakan di depan hakim.

Akibat-akibat dari terjadinya wanprestasi diatas, lebih jelasnya dijabarkan sebagai berikut :

a. Ganti rugi.

Ganti rugi sering diperinci dalam tiga unsur yakni biaya, rugi dan bunga. Biaya adalah segala pengeluaran dan perongkosan yang nyata-nyata sudah dikeluarkan oleh salah satu pihak. Yang dimaksudkan dengan istilah rugi adalah kerugian karena kerusakan barang-barang kepunyaan debitur yang diakibatkan oleh kelalaian si debitur. Yang dimaksudkan dengan bunga adalah kerugian yang berupa kehilangan keuntungan, yang sudah dibayangkan atau dihitung oleh kreditur.

b. Pembatalan perjanjian.

Mengenai pembatalan perjanjian atau juga dinamakan pemecahan perjanjian, sebagai sanksi kedua atas kelalaian seorang debitur, mungkin ada orang yang tidak dapat melihat sifat pembatalannya atau pemecahan tersebut sebagai suatu hukuman karena debitur menganggap dibebaskan dari kewajiban memenuhi prestasi. Pembatalan perjanjian, bertujuan membawa kedua belah pihak kembali pada keadaan sebelum perjanjian diadakan. Kalau suatu pihak sudah menerima sesuatu dari pihak yang lain, baik uang maupun barang, maka itu harus dikembalikan.

Pasal 1266 KUHPerdata menyatakan bahwa: 
"Syarat batal dianggap selamanya dicantumkan dalam perjanjian-perjanjian yang timbal balik, manakala salah satu pihak tidak memenuhi kewajibannya. Dalam hal demikian perjanjian tidak batal demi hukum, tetapi pembatalan harus dimintakan kepada hakim. Permintaan ini juga harus dilakukan, meskipun syarat batal mengenai tidak dipenuhinya kewajiban itu dinyatakan dalam perjanjian. Jika syarat batal tidak dinyatakan dalam perjanjian, hakim leluasa menurut keadaan atas permintaan si tergugat, untuk memberikan suatu jangka waktu guna kesempatan memnuhi kewajibannya, jangka waktu mana tidak boleh lebih dari satu bulan.”

Berdasarkan ketentuan pasal tersebut diatas maka jelas bahwa pembatalan perjanjian tidak terjadi secara otomatis pada waktu debitur nyata-nyata melalaikan kewajibannya, akan tetapi harus dimintakan kepada hakim dan disebutkan dengan jelas, bahwa perjanjian itu tidak batal demi hukum.

c. Peralihan resiko

Peralihan resiko sebagai sanksi ketiga atas kelalaian seorang debitur disebutkan dalam Pasal 1237 Ayat (2) KUHPerdata. Yang dimaksudkan dengan resiko adalah kewajiban untuk memikul kerugian jika terjadi suatu peristiwa diluar kesalahan salah satu pihak, yang menimpa barang yang menjadi objek perjanjian.

d. Pembayaran biaya perkara

Tentang pembayaran ongkos biaya perkara sebagai sanksi keempat bagi seorang debitur yang lalai adalah tersimpul dalam suatu peraturan Hukum Acara, bahwa pihak yang dikalahkan diwajibkan membayar biaya perkara. Seorang debitur yang lalai tentu akan dikalahkan kalau sampai terjadi suatu perkara di depan hakim.

Dalam pelaksanaan perjanjian sewa menyewa rumah susun terkadang terdapat permasalahan antara pengelola yaitu UPT Rusunawa Dinas Pekerjaan Umum Perumahan dan Kawasan Permukiman dengan penyewa yang menimbulkan sengketa sewa menyewa yang berakibat pada pemutusan atau peninjauan kembali hubungan sewa menyewa tersebut. Sebenarnya sengketa ini merupakan sengketa perdata biasa dan penyelesaiannya pun mudah dan sederhana karena segala sesuatunya dikembalikan lagi kepada kontrak atau perjanjian sewa menyewa itu sendiri, yang didasari pada izin yang diberikan oleh Dinas Pekerjaan Umum Perumahan dan Kawasan Permukiman yang menyatakan bahwa penyelesaian sengketa tidak bisa dilakukan dengan sederhana karena harus dengan prosedur yang telah ditetapkan dalam peraturan-peraturan yang berlaku.

Penyewa rumah susun disebutkan berada dalam keadaan wanprestasi, apabila dia dalam melakukan pelaksanaan prestasi perjanjian telah lalai sehingga terlambat dari jadwal waktu yang ditentukan atau dalam melaksanakan prestasi tidak menurut sepatutnya. Seperti yang telah disinggung, akibat yang timbul dari wanprestasi ialah keharusan atau kemestian bagi penyewa membayar ganti rugi. Atau dengan adanya wanprestasi oleh salah satu pihak, pihak yang lainnya dapat menuntut pembatalan 
perjanjian. Sebab dengan tindakan penyewa dalam melaksanakan kewajiban tidak tepat waktu atau tidak sepatutnya, jelas merupakan pelanggaran hak bagi yang menyewakan.

Wanprestasi memberikan akibat hukum terhadap pihak yang melanggar dan memberikan konsekuensi terhadap munculnya hak dari pihak yang dirugikan untuk menuntuk pihak yang melakukan wanprestasi untuk memberikan ganti rugi, sehingga oleh hukum diharapkan agar tidak ada satu pihak pun yang dirugikan karena wanprestasi tersebut. Apabila terjadi wanprestasi terhadap perjanjian sewa menyewa rumah susun yang sebelumnya telah disepakati oleh kedua belah pihak, maka para pihak yang merasa dirugikan harus dapat membuktikan kerugian yang dialami tersebut. Terjadinya wanprestasi dalam suatu perjanjian membawa konsekuensi bagi pihak yang melakukannya. Apabila salah satu pihak merasa dirugikan akibat wanprestasi atas perjanjian sewa menyewa yang telah disepakati sebelumnya maka akibat hukumnya pihak UPT Rusunawa Dinas Pekerjaan Umum Perumahan dan Kawasan Permukiman dapat menuntut tanggungjawab. Tuntutan wanprestasi dapat berupa pembatalan perjanjian, pemenuhan perjanjian, pembayaran ganti rugi, pembatalan perjanjian dengan ganti rugi, pemenuhan perjanjian dengan ganti rugi.

Adapun akibat hukum wanprestasi yang akan diterima oleh penyewa apabila tidak membayar sewa di rumah susun grabinaharapan yaitu akan diberikan surat peringatan kepada penyewa agar segera membayar sewa rumah susunnya. Tetapi apabila peringatan tersebut tidak di laksanakan oleh penyewa hingga surat peringatan ketiga maka perjanjian sewa menyewa tersebut akan diputuskan atau diakhiri oleh pihak yang menyewakan yaitu Dinas Pekerjaan Umum Perumahan dan Kawasan Permukiman UPT Rusunawa sesuai dengan yang telah disepakati sebelumnya didalam perjanjian.

Sebagaimana yang telah kita ketahui, hukum perdata itu mengatur hubungan antara orang yang satu atau lebih dengan satu orang atau lebih lainnya yang menimbulkan hak dan kewajiban diantara mereka yang membuat perjanjian. Apabila salah satu dari pihak tersebut tidak memenuhi kewajibannya atau melanggar hak orang lain, maka pihak yang yang terlanggar hak nya tersebut dapat meminta bantuan dari Negara.

Dalam hukum perdata, Negara tidak akan mencanpuri urusan seseorang tersebut apabila pihak-pihak tersebut yang bersengketa merasa haknya dilanggar tidak mengajukan tuntutan atau gugatan ke pengadilan. Dalam hal ini terlebih dahulu diperbolehkan kepada para pihak untuk menyelesaikan masalahnya sendiri dengan cara musyawarah mufakat untuk jalur kekeluargaan. Akan tetapi apabila cara ini tidak mendapatkan jalan keluar maka masalah tersebut dapat dimintakan kepada Negara yang siap melindungi hak seseorang tersebut yang terlanggar haknya. Dalam hal ini yang mempunyai wewenang adalah Pengadilan Negeri untuk menyelesaikan sengketa dengan seadil-adilnya berdasarkan hukum acara perdata dengan mengikat peraturan atau ketentuan yang berkaitan dengan permasalahan. 
Upaya penyelesaian sengketa antara penyewa dengan UPT Rusunawa Dinas Pekerjaan Umum Perumahan dan Kawasan Permukiman Rumah Susun Grahabinaharapan dalam hal terjadinya keterlambatan pembayaran uang sewa yaitu diselesaikan dengan cara melakukan musyawarah mufakat atau jalur kekeluargaan. Hanya saja dalam proses penyelesaian sengketa dengan mengambil jalur kekeluargaan tidak mencapai kata mufakat maka upaya penyelesaian yang terakhir yaitu jalur hukum.

\section{Simpulan}

Pelaksanaan sewa menyewa rumah susun di Grahabinaharapan dilaksanakan dengan bentuk tertulis, suatu perjanjian dapat berakhir apabila jangka waktu yang telah ditentukan telah berakhir. Akibat hukum wanprestasi dalam perjanjian sewa menyewa rumah susun di Grahabianaharapan adalah diberikan surat peringatan kepada penyewa agar segera membayar sewa rumah susun. Tetapi apabila peringatan tersebut tidak di laksanakan oleh penyewa hingga surat peringatan ketiga maka perjanjian sewa menyewa tersebut akan diputuskan atau diakhiri oleh pihak yang menyewakan yaitu Dinas Pekerjaan Umum Perumahan dan Kawasan Permukiman UPT Rusunawa sesuai dengan yang telah disepakati sebelumnya didalam surat Perjanjian sewa menyewa.

\section{Daftar Pustaka}

\section{Buku}

Budiman, Sinaga. (2005). Hukum Kontrak dan penyelesaian sengketa. Jakarta: PT Raja Grafindo Tinggi

Kartini Mulyadi, Gunawan Widjaja. (2008). Perikatan Yang Lahir Dari Perjanjian. Jakarta: Rajawali Pers.

Mukti Fajar ND, Yulianto Achmad. (2009). Dualisme Penelitian Hukum Normatif \& Empiris. Yogyakarta: Pustaka Pelajar.

Subekti. (2014). Aneka Perjanjian. Surabaya: Citra Bakti.

\section{Jurnal}

Azahery Insan Kamil, (2014) "Hukum Kontrak dalam Perspektif Komparatif (Menyorot Perjanjian Bernama dengan Perjanjian Tidak Bernama)", Jurnal Media Hukum, Vol. VIII, No. 2, ISSN: 1693-0819

Dwi Ratna Indri.H, (2014) "Kontrak dalam Kitab Undang-undang Hukum Perdata dan Hukum Islam”, Jurnal Media Hukum, Vol. I, No 1, ISSN: 2355-2646

Erna Susanti, (2017) "Tinjauan Hukum Terhadap Pelaksanaan Sewa Menyewa", Jurnal Media Hukum, Vol. III, No. 5, ISSN: 2337-4608

Ery Agus Priyono, (2016) “Tinjauan Yuridis perjanjian Sewa Menyewa Depo Container Yard PT Kawasan Berikat Nusantara Persero (Studi Kasus Putusan MA No.116/PK/Pdt/2015)", Diponegoro Law Jurnal, Vol. V, No 4

Evalina Yessica, (2014) "Karakteristik dan Kaitan Perbuatan Melawan Hukum dan Wanprestasi”, Jurnal Media Hukum, Vol. I No. 2, ISSN: 2355-2646 
Fitriani amas, (2017) "Aspek Pelaksanaan Perjanjian Jual Beli berdasarkan KUHPerdata", Jurnal Ilmu Hukum Legal Opinion, Vol. V, No 4, ISSN : 2527-9505

Hendra Taufik, Yesi Arianti, (2013) "Analisis Kelayakan Ekonomi Rumah Susun Sederhana Sewa Pekanbaru", E-Jurnal Sains dan Teknologi, Vol. 12, No. 1, ISSN : $1412-6257$

Sedyo Prayogo, (2016) "Penerapan Batas-batas Wanprestasi dan Perbuatan Melawan Hukum dalam Perjanjian", Jurnal Media Hukum, Vol. III No.2

Suroso, (2014) "Pelaksanaan Perjanjian Sewa Menyewa Phonton Antara Penyewa dan pemilik dikota Pontianak", e-Jurnal Gloria Yuris, Vol. II, No 2

\section{Wawancara}

Wawancara dengan Ibu Sri Rismawanti selaku kepala UPT Pusat Bisnis Dinas Perindustrian dan Perdagangan Pada Tanggal 15 Mei 2019.

\section{Perundang undangan}

Kitab Undang-Undang Hukum Perdata (KUHPerdata)

Undang-Undang Nomor 20 Tahun 2011 Tentang Rumah Susun

Peraturan Wali Kota Yogyakarta Nomor 44 Tahun 2009 Tentang Pengelolaan Rumah Susun Sederhana Sewa Milik Pemerintah Kota Yogyakarta 